\title{
Posterior sagittal anorectoplasty in anorectal anomalies: clinical, manometric and profilometric
} evaluation

\author{
Discipline of Pediatric Surgery, Universidade Federal de São Paulo - \\ Escola Paulista de Medicina (Unifesp-EPM), São Paulo, Brazil
}

INTRODUCTIRN

Posterior sagittal anorectoplasty, which was proposed by Alberto Peña and Pieter de Vries in $1982,{ }^{1}$ revolutionized the surgical treatment of anorectal anomalies. This technique provided better understanding of the anatomical relationships between the structures involved in such malformations. Nonetheless, anorectal anomalies continue to be difficult to treat, even today.

口BJECTIVE

The aim of this study was to evaluate patients with anorectal anomalies who underwent surgery using the technique of posterior sagittal anorectoplasty, from the point of view of fecal continence and pressure profile, using computerized anorectal manometry with continuous perfusion and profilometry.

METHOD

Eighty-two children with anorectal anomalies were evaluated within the Pediatric Surgery Division, Department of Surgery, Universidade Federal de São Paulo - Escola Paulista de Medicina (Unifesp-EPM), between 2001 and 2004. Among these, there were 45 cases of high anorectal anomaly and 37 of intermediate anomaly. The children's ages were between 12 and 204 months, and there were 46 males and 36 females. All of them were at a late postoperative stage, i.e. more than nine months after the surgical procedure to correct anorectal malformation.

These patients were studied prospectively from the clinical point of view, and by means of computerized anorectal manometry using the perfusion method and profilometry, with regard to their capacity for fecal continence.

\section{BUREICAL PROCEDURES}

All the patients had initially undergone temporary colostomy in the descending colon with two openings (proximal and distal), 24 hours after their birth. Posterior sagittal anorectoplasty was performed subsequently, at a mean of four months of life. This procedure comprised a sagittal incision between the coccyx and perineum that extended to the parasagittal fibers of the external sphincter muscle of the anus and the sphincter muscle complex. Then full dissection was done using a electrical muscle stimulator to identify the different parts of the muscular sphincter complex.

The rectal pouch was identified and mobilized. It was then dissected, opened and enveloped within muscle tissue of the sphincter muscle complex. Following this, the anorectoplasty was completed.

Anal dilatation procedures were begun two weeks after the anorectoplasty, and lasted for up to eight weeks. They were continued until adequate canal caliber was achieved $(14 \mathrm{~mm})$, when the colostomy could be closed and the intestinal lumen reconstructed.

\section{POBTOPERATIVE EVALUATION}

Six months after the reconstruction of the intestinal transit, the patients were evaluated clinically and by means of anorectal manometry and profilometry.

\section{A. EVALUATION IF FEcal CONTINENCE}

The patients were divided into three groups:

- Continent: patients who evacuated once or twice a day, with feces of normal appearance and consistency, without episodes of escape and without staining their underwear. Rectal examination showed good contractility of the sphincter muscle complex;

- Partially continent: individuals who evacuated three to five time a day, with feces of pasty consistency and episodes of escapes, and frequent soiling of underwear. The anus had a regular appearance upon inspection, often with small areas of prolapsed mucosa of dirty appearance. Rectal examination showed regular contractions
- Pedro Félix Vital Júnior

- José Luiz Martins

- Fábio Luís Peterlini

\section{ABSTRACT}

CONTEXT AND OBJECTIVE: Anorectal malformations comprise a spectrum of anomalies that continue to be difficult to treat, even today. The aim was to evaluate the fecal continence of children who underwent posterior sagittal anorectoplasty due to anorectal malformations, via computerized anorectal manometry and profilometry.

DESIGN AND SETTING: Prospective study at Universidade Federal de São Paulo.

METHOD: 82 patients ( $56.1 \%$ boys; $43.9 \%$ girls) of mean age 85.5 months were evaluated. They were divided into continent, partially continent and incontinent groups. Age, sex, manometric variables and profilometric parameters were studied. The results were statistically analyzed.

RESULTS: Among the 82 patients, $37.8 \%$ were continent, $25.6 \%$ were partially continent and $36.6 \%$ were incontinent. The overall mean resting pressure was $22 \mathrm{mmHg}$, and the means for the continent, partially continent and incontinent groups were, respectively, $30.7 \mathrm{mmHg}$, $23 \mathrm{mmHg}$ and $14.7 \mathrm{mmHg}$. The overall mean pressure response to voluntary contraction was $56 \mathrm{mmHg}$, and the means for the groups were $65.4 \mathrm{mmHg}, 55.8 \mathrm{mmHg}$ and $46.6 \mathrm{mmHg}$ respectively. The rectosphincteric reflex was absent in $82.9 \%$ of the cases. In the profilometry analysis for all patients together, blue 20 to $50 \mathrm{mmHg}$ ) and yellow (50 to $80 \mathrm{mmHg}$ ) were predominant, and there was a similar distribution for the continent and partially continent patients. However, among the incontinent patients, green $(<20 \mathrm{mmHg}$ ) and blue prevailed.

CONCLUSIONS: Manometric and computerized profilometric analyses were an excellent method for postoperative evaluations on patients with intermediate and high anorectal anomalies, and for therapeutic planning.

KEY WORDS: Child. Anal canal. Imperforate anus. Manometry. Fecal incontinence. 
only in the upper and lower portions of the sphincter muscle complex;

- Fecally incontinent: patients who evacuated more than five times a day, with feces of liquid consistency and constant total fecal loss. The anus had an abnormal appearance, either with a pronounced opening or with significant prolapsed mucosa, with feces visibly leaking out. Rectal examination showed segments of the sphincter muscle complex.

\section{B. EVALUATION BY MEANB gF COMPUTERIZED ANORECTAL MANOMETRY USINE THE PERFUSION TECHNIQUEE}

A flexible catheter of four millimeters ( $\mathrm{mm}$ ) ranged orifices and a lumen to enable inflation of a latex balloon with a maximum capacity of 200 milliliters $(\mathrm{ml})$, at its tip. The following variables were evaluated during the examination: resting pressure (RP), length of the anal canal, sphincter pressure response to coughing (CP), pressure response to voluntary contraction (VCP), maximum pressure obtained on the pressure curve (MP), pressure response during perianal stimulation (PAS), pressure curve analysis and rectosphincteric reflex (RSR). Three-dimensional graphics of the anorectal canal weak contractions, or their absence, in all in diameter was utilized, with four radially-ar-

were produced from the tracings relating to the pressure curve (profilometry), to establish indices for total asymmetry, anorectal canal segment asymmetry and rectal volume $\left(\mathrm{cm} \mathrm{x} \mathrm{cmHg}^{2}\right)$.

The catheter was connected to a fourchannel pressure receptor, with a pneumatic $\mathrm{CO}_{2}$ system that kept the infusion pressure at one atmosphere (atm), with continuous flow of distilled water at the rate of 0.56 milliliters $/$ minute $(\mathrm{ml} / \mathrm{min}){ }^{2,3}$

The pressure data obtained were amplified, and the results were recorded and analyzed with the aid of the Proctomaster software (Dynamed; Dynapack MPX 850), with pressures presented in millimeters of mercury $(\mathrm{mmHg})$.

After identifying the region of greatest pressure, the catheter was reintroduced in such a way as to position the perfusion orifices within this segment of greatest pressure, to make recordings, and was then fixed there.

From the tracings acquired in building up pressure curves from the four perfusion channels, obtaining pressure readings from the four quadrants, the computer program generated three-dimensional tracings of the anorectal canal. This made it possible to study the total and segmental asymmetry indices for this canal, the rectal volume $\left(\mathrm{cm} \mathrm{x} \mathrm{cmHg}^{2}\right)$, and also the pressure distribution on the anorectal wall. The latter was translated via the program

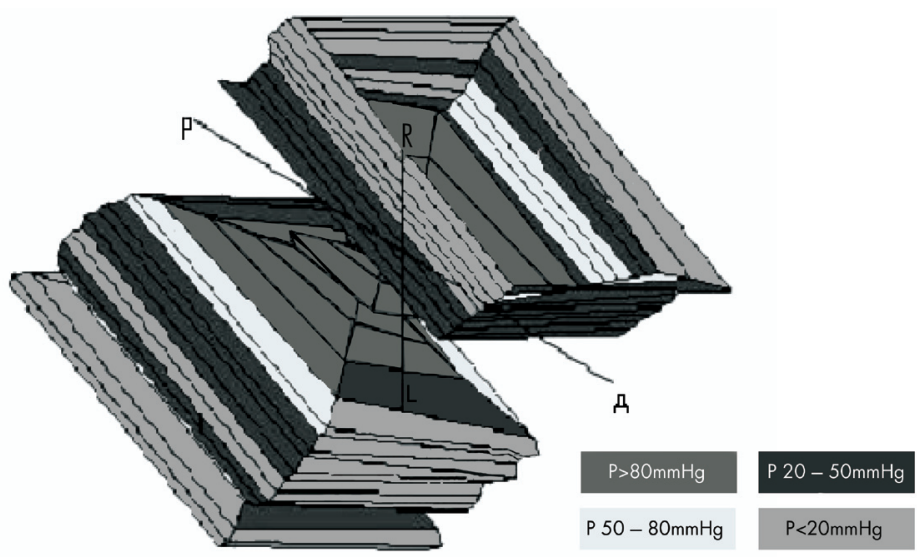

Figure 1. Profilometry: computer graphic of the pressure curves in the anal canal, obtained using continuous flow computerized anorectal manometry in children who underwent posterior sagittal anorectoplasty. Example of sphincter muscle complex with adequate pressure profile in anorectal canal. $\mathbf{A}=$ anterior; $\mathbf{P}=$ posterior; $\mathbf{R}=$ right; $\mathbf{L}=$ left.

Table 1. Distribution profile of fecal continence in sample of children who underwent posterior sagittal anorectoplasty

\begin{tabular}{lcc}
\hline & $\mathbf{n}$ & $\%$ \\
\hline Continent individuals & 31 & 37.8 \\
Partially continent individuals & 21 & 25.6 \\
Incontinent individuals & 30 & 36.6 \\
Total & $\mathbf{8 2}$ & $\mathbf{1 0 0}$ \\
\hline
\end{tabular}

into a sequence of colors corresponding to pressures, on a previously established scale (green: < $20 \mathrm{mmHg}$; blue: $20-50 \mathrm{mmHg}$; yellow: $50-$ $80 \mathrm{mmHg}$; red: > $80 \mathrm{mmHg}$ ) (Figure 1).

For the quantitative variables, means and medians were utilized to summarize the information, and standard deviations, minimums and maximums to indicate the variability of the data. Absolute (n) and relative frequencies (\%) were presented for the non-parametric data, and also the following statistical tests: chi-squared, analysis of variance (ANOVA), Tukey, nonparametric Kruskal-Wallis, non-parametric Mann-Whitney and Student's t.

For all of these, the significance level adopted was $5 \%$. Thus, associations or statistical differences between groups were considered valid when the results from the tests presented values less than 0.05 ( $\mathrm{p}$-value less than or equal to 0.05 ).

RESULTS

The numbers of patients in the three categories of fecal continence (continent, partially continent and incontinent) were similar, as shown in Table 1 . There was predominance of high anorectal anomalies among the incontinent patients, and this is shown in Table 2 . The means, medians and standard deviations of quantitative variables for all 82 patients are presented in Table 3.

The patient distribution was analyzed in relation to sex, presence or absence of rectosphincteric reflex, the behavior of the pressure curves with regard to shapes and pressure levels, and profilometry mapping, for the continent, partially continent and incontinent groups of patients. The results from this are presented in Table 4.

The distribution by age groups, mean resting pressure, voluntary contraction pressure, anal canal length, total and segmental anorectal canal asymmetry indices and rectal volume was evaluated separately for the continent, partially continent and incontinent groups of patients. These results are presented in Table 5 .

It was observed that there were differences between the groups with regard to the variables of age, resting pressure and voluntary contraction pressure. To identify which groups presented differences between each other, multiple comparisons were performed, as shown in Table 6.

It was observed from the results above that there were differences in age between the continent and incontinent patients, such that the incontinent patients on average presented greater ages. It was also seen that there were differences in resting pressure between all the 
groups, such that the incontinent patients presented the lowest pressure values, followed by the partially continent patients and then the continent patients, with the greatest mean values. Furthermore, there were differences in voluntary contraction pressure between the continent and incontinent patients, such that the incontinent patients on average presented lower values.

Table 7 presents the linear correlations between the variables of age, resting pressure, voluntary contraction pressure and anal canal length. The index utilized was Pearson's correlation coefficient, varying from -1 to +1 , which indicates stronger correlations as the values come closer to the extremities. The greatest value found for Pearson's correlation coefficient was 0.60 , thereby showing that there was a tendency towards a positive linear association between the resting pressure and the voluntary contraction pressure, i.e. the greater the value of the resting pressure was, the greater the voluntary contraction pressure. The correlations between the other variables were low in magnitude. There was no great correlation between age and any other variable.

DISCUSSION

Despite advances in surgical techniques, the preservation of the mechanisms essential for fecal continence and voluntary control over evacuations is often deficient following surgical treatment of intermediate and high anorectal anomalies. ${ }^{4-6}$
Various researchers ${ }^{7-14}$ have done electrophysiological anorectal evaluations by means of anorectal manometry. This has specific applications in cases of intestinal constipation; fecal incontinence; post-traumatic, postoperative and infectious sequelae of the anorectal region; and, especially, in postoperative evaluation of anorectal malformations.

We had overall predominance of male individuals (56.1\%) among our patients. However, when they were divided into the three specific groups of continent, partially continent and incontinent patients, the major- ity of the continent individuals were female (61.3\%; $\mathrm{p}=0.011)$.

The median age allowed us to make a reliable assessment of the degree of continence, in relation to when continence is physiologically acquired. In general, this is at preschool age, even though some authors ${ }^{15,16}$ have believed otherwise and have published studies on anorectal anomalies using anorectal manometry among premature and low birth weight children, while obviously making allowances for their physiological characteristics and the absence of systemic manifestations that would interfere in the results.

Table 2. Distribution of high and intermediate anorectal anomalies in the continent, partially continent and incontinent groups of children who underwent posterior sagittal anorectoplasty

\begin{tabular}{lcccccc}
\hline \multirow{2}{*}{ Type of anorectal anomaly } & \multicolumn{2}{c}{ Continent } & \multicolumn{2}{c}{ Partially continent } & \multicolumn{2}{c}{ Incontinent } \\
\cline { 2 - 8 } & $\mathbf{n}$ & $\%$ & $\mathbf{n}$ & $\%$ & $\mathbf{n}$ & $\%$ \\
\hline High & 12 & 38.7 & 11 & 52.4 & 22 & 73.3 \\
Intermediate & 19 & 61.3 & 10 & 47.6 & 8 & 26 \\
\hline
\end{tabular}

Table 3. Presentation of the means, medians and standard deviations for the variables among children who underwent posterior sagittal anorectoplasty: age, resting pressure (RP), voluntary contraction pressure (VCP), anal canal length, total asymmetry index (TAI), segmental asymmetry index (SAl) and rectal volume (RV), from anorectal manometry ( $n=82)$

\begin{tabular}{lccccc}
\hline & Mean & Median & Standard deviation & Minimum & Maximum \\
\hline Age (months) & 85.5 & 72.0 & 50.6 & 12.0 & 204.0 \\
RP $(\mathrm{mmHg})$ & 22.9 & 20.0 & 10.3 & 7.0 & 47.0 \\
VCP $(\mathrm{mmHg})$ & 56.0 & 53.0 & 18.3 & 16.0 & 106.0 \\
Anal canal $(\mathrm{cm})$ & 2.5 & 2.0 & 0.9 & 1.0 & 5.0 \\
TAl $(\%)$ & 29.8 & 28.5 & 10.3 & 11.1 & 60.0 \\
SAl $(\%)$ & 25.2 & 24.0 & 12.1 & 2.3 & 54.7 \\
RV $\left(\mathrm{cm} \times \mathrm{cmHg}^{2}\right)$ & 280.3 & 151.3 & 382.9 & 9.2 & 1349.0 \\
\hline
\end{tabular}

Table 4. Comparisons between the continent, partially continent and incontinent groups of children who underwent posterior sagittal anorectoplasty, in relation to the qualitative variables of sex, rectosphincteric reflex (RSR), pressure curve shape, pressure curve level and profilometry

\begin{tabular}{|c|c|c|c|c|c|c|c|c|}
\hline & & \multicolumn{6}{|c|}{ Group } & \multirow{3}{*}{$\begin{array}{c}\text { Descriptive } \\
\text { level } \\
\text { (p-value) }\end{array}$} \\
\hline & & \multicolumn{2}{|c|}{ Continent } & \multicolumn{2}{|c|}{ Partially continent } & \multicolumn{2}{|c|}{ Incontinent } & \\
\hline & & $n$ & $\%$ & $n$ & $\%$ & $n$ & $\%$ & \\
\hline \multirow[t]{2}{*}{ Sex } & male & 12 & $38.7 \%$ & 11 & $52.4 \%$ & 23 & $76.7 \%$ & \multirow{2}{*}{0.011} \\
\hline & female & 19 & $61.3 \%$ & 10 & $47.6 \%$ & 7 & $23.3 \%$ & \\
\hline \multirow[t]{2}{*}{ RSR } & absent & 20 & $64.5 \%$ & 20 & $95.2 \%$ & 28 & $93.3 \%$ & \multirow{2}{*}{0.003} \\
\hline & present & 11 & $35.5 \%$ & 1 & $4.8 \%$ & 2 & $6.7 \%$ & \\
\hline \multirow[t]{2}{*}{ Pressure curve shape } & abnormal & 12 & $38.7 \%$ & 10 & $47.6 \%$ & 23 & $76.7 \%$ & \multirow{2}{*}{0.009} \\
\hline & normal & 19 & $61.3 \%$ & 11 & $52.4 \%$ & 7 & $23.3 \%$ & \\
\hline \multirow[t]{3}{*}{ Pressure curve level } & low & 3 & $9.7 \%$ & 7 & $33.3 \%$ & 17 & $56.7 \%$ & \multirow{3}{*}{0.003} \\
\hline & normal & 16 & $51.6 \%$ & 8 & $38.1 \%$ & 9 & $30.0 \%$ & \\
\hline & High & 12 & $38.7 \%$ & 6 & $28.6 \%$ & 4 & $13.3 \%$ & \\
\hline \multirow[t]{4}{*}{ Profilometry } & Green & 3 & $9.7 \%$ & 2 & $9.5 \%$ & 13 & $43.3 \%$ & \multirow{4}{*}{0.003} \\
\hline & Blue & 15 & $48.4 \%$ & 12 & $57.1 \%$ & 15 & $50.0 \%$ & \\
\hline & Yellow & 12 & $38.7 \%$ & 5 & $23.8 \%$ & 2 & $6.7 \%$ & \\
\hline & Red & 1 & $3.2 \%$ & 2 & $9.5 \%$ & & & \\
\hline
\end{tabular}


Table 5. Comparison between the continent, partially continent and incontinent groups of children who underwent posterior sagittal anorectoplasty and the means, medians and standard deviations for the quantitative variables of age, resting pressure, voluntary contractions, anal canal length, total and segmental asymmetry indices and rectal volume

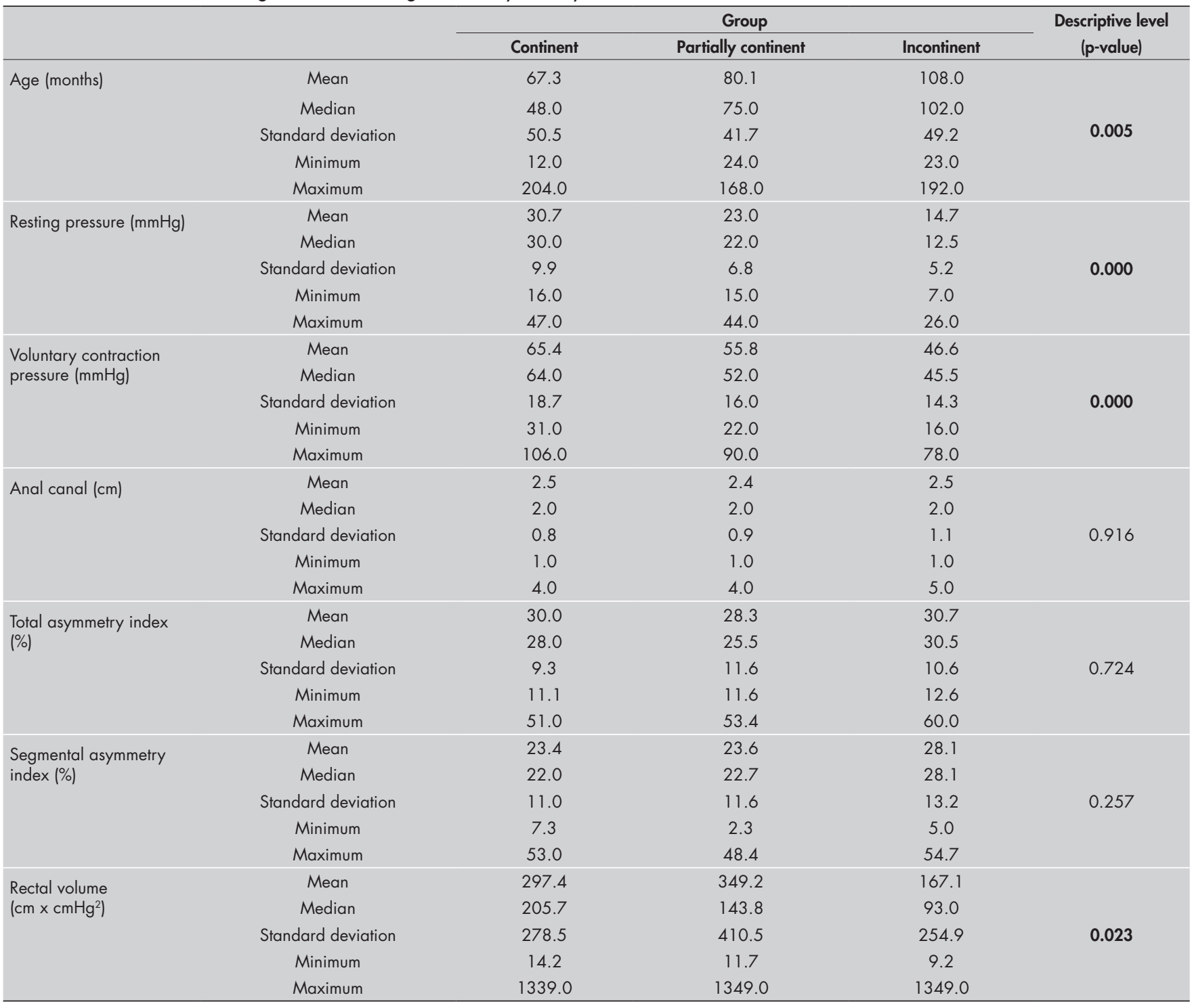

Table 6. Multiple comparisons to identify statistical significance between pairs, in relation to age (months), resting pressure (mmHg) and voluntary contraction pressure $(\mathrm{mmHg})$ among children who underwent posterior sagittal anorectoplasty

\begin{tabular}{lccc}
\hline Groups compared & $\begin{array}{c}\text { Age } \\
\text { p-value }\end{array}$ & $\begin{array}{c}\text { Resting pressure } \\
\text { p-value }\end{array}$ & $\begin{array}{c}\text { Voluntary contraction pressure } \\
\text { p-value }\end{array}$ \\
\hline Continent and partially continent & 0.613 & 0.006 & 0.106 \\
Continent and incontinent & 0.004 & 0.000 & 0.000 \\
Partially continent and incontinent & 0.108 & 0.000 & 0.130 \\
\hline
\end{tabular}

Table 7. Linear correlations between the quantitative variables of age, resting pressure (RP), voluntary contraction pressure (VCP), anal canal length and rectal volume among children who underwent posterior sagittal anorectoplasty

\begin{tabular}{lcccc}
\hline & Age (months) & RP & VCP & Anal canal \\
\hline Age (months) & 1 & & & \\
RP (mmHg) & -0.28 & 1 & 1 & 1 \\
VCP $(\mathrm{mmHg})$ & -0.21 & 0.60 & 0.21 & 0.26 \\
Anal canal $(\mathrm{cm})$ & -0.13 & 0.14 & 0.11 & 0.08 \\
RV $\left(\mathrm{cm} \times \mathrm{cmHg}^{2}\right)$ & -0.17 & 0.19 & 0.26 \\
\hline
\end{tabular}


We found continence in $37.8 \%$ of the cases in our sample, partial continence in $25.6 \%$ and incontinence in $36.6 \%$. We have attributed an important role to the resting pressure, in the process of acquiring continence, although we are aware that, especially in cases of high anorectal anomalies, this variable is related to the presence of a striated muscle complex, particularly the external anal sphincter muscle. ${ }^{17-19}$

Muscle activity was studied in our sample by means of the behavior of the pressure curves, which were found to present normal shapes and pressure intensity levels in a little under half of the cases: $45.1 \%$ and $40.2 \%$, respectively. When these results were compared with the capacity for continence among the 82 children evaluated, we observed that the sum of the percentages of continent and partially continent patients (63.4\%) practically coincided with the sum of the percentages of curves with normal and high pressure intensity levels (67\%). This association could also be seen between the incontinent individuals (36.6\%) and the percentage of curves with a pressure intensity level of low power (32.95\%).

These graphical representations made it possible to identify the patients with amputated curves, thus revealing a compromised external anal sphincter muscle. Likewise, large amplitude curves represented postoperative scar stenosis, and tracings with rectified ascending curves denoted irregularities of the puborectal bundle of the levator ani muscle, among others.

Curves of low-power pressure intensity were related to patients with low capacity for sphincteric contractions, and these were thus children with low potential for continence.

Low-amplitude curves with low pressure intensity levels led us to anorectal anomalies of greater therapeutic complexity, with deficient or even non-existent striated sphincteric musculature, or to a reconstruction with inadequate localization of the neo-anus during the posterior sagittal anorectoplasty. This pressure curve pattern was found in $9.7 \%$ of the continent patients, $33.3 \%$ of the partially continent and $56.7 \%$ of the incontinent patients.

There were curves of high pressure intensity level in $13.3 \%$ of the patients in the incontinent group. In fact, there were patients who frequently soiled their underwear with feces. They presented absence of effective evacuations that was probably due to postoperative scar stenosis, with or without associated inefficiency in anal dilatation sections. We found high-amplitude curves with high pressure levels for these children, and large rectal volumes. These children could be considered to have pseudo-incontinence, which would probably present therapeutic possibilities.

The mean resting pressure observed was $22.9 \mathrm{mmHg}$ and the mean voluntary contraction pressure was $56 \mathrm{mmHg}$. These values, despite being within the normal limits in relation to those presented in manometric studies, were always close to the lower limit. The mean for the voluntary contraction pressure was practically twice the resting pressure, which is generally expected when continence capacity is investigated.

Measurement of the pressure in the anal canal has been a useful and commonly used way of assessing sphincter function and providing valuable information. ${ }^{20-24}$ Our analysis of the mean resting pressure showed that the greatest pressure levels were among the continent patients $(30.7 \mathrm{mmHg})$, in relation to the partially continent $(23 \mathrm{mmHg})$ and incontinent patients $(14.7 \mathrm{mmHg})$, and these pressure differences were very representative from a statistical point of view $(\mathrm{p}=0.001)$.

In a general manner, these mean resting pressures were low in the three groups evaluated, and similar values have been found by other authors. ${ }^{25}$ It is our understanding that the threshold levels for resting pressure among patients with high and intermediate anorectal anomalies are a reflection of the abnormalities in their anatomical development. Likewise, lesions of the neuromuscular structures essential for fecal continence that occur during surgical correction may interfere in the short and long-term prognosis.

However, we found that threshold pressure values could provide states of full continence, partial continence or incontinence, without interference from other elements in this process, for example fecal consistency.

There was a tendency towards linear growth when we correlated resting pressures and voluntary contraction pressures, which makes us believe even more in the active participation of the external anal sphincter in maintaining the resting pressure among patients treated for high and intermediate anorectal anomalies.

In studying the behavior of the pressure response to voluntary contraction, which is generated primarily by the external sphincter muscles of the anus and the levator ani muscle, with major participation by its puborectal sling, ${ }^{26}$ we found higher values among the continent patients $(65.4 \mathrm{mmHg})$ than among the partially continent $(55.8 \mathrm{mmHg})$ and incontinent patients $(46.6 \mathrm{mmHg})$, with $\mathrm{p}<0.0001$.
This statistical significance between the continent and incontinent groups of patients was large. The partially continent individuals presented mean voluntary contraction pressures that were very close to those of the continent patients, which makes us optimistic about their prognoses, with the application of appropriate exercises to improve their fecal continence.

Reflex relaxation of the internal sphincter muscle of the anus induced by rectal distension is associated with suppression of the electrical oscillations in this sphincter. ${ }^{27-29}$ Rectosphincteric reflex was found in $17.1 \%$ of the 82 patients examined. When the patient groups were analyzed separately, we observed that rectosphincteric reflex was detected in $35.5 \%$ of the continent children, $4.8 \%$ of the partially continent and $6.7 \%$ of the incontinent children, i.e. with very distinct distribution between these groups.

The presence of rectosphincteric reflex was attributed to the fact that we had patients with anorectal anomalies of intermediate type in our sample. The internal anal sphincter may be present in such patients. The presence of rectosphincteric reflex in patients with high anorectal anomalies may be a reactional response by the external sphincter muscle to favor the passage of feces, most probably in a conscious manner. In some other cases, it may be an artifact of the examination. Thus, it remains unclear whether or not rectosphincteric reflex is the best indicator for anorectal function following surgery to correct anorectal anomalies. ${ }^{30}$

The lengths of the anal canal in the continent, partially continent and incontinent groups of patients presented a small range of means, from 2.4 to 2.5 centimeters. According to the results presented, the participation of the length of the functional anal canal in the capacity for fecal continence among patients with high and intermediate anorectal anomalies following posterior sagittal anorectoplasty did not show statistical significance between the groups evaluated. Some researchers have attributed to the length of the functional anal canal an active participation in maintaining continence, either separately or in association with other anatomical elements. ${ }^{31,32}$

We believe that computerized profilometry is one of the major innovatory contributions towards patient care following posterior sagittal anorectoplasty. It is capable of providing reliable information regarding the three-dimensional topography of the anorectal canal, and also regarding the distribution of the pressures involved in the process of acquiring anorectal fecal continence, thus greatly assisting in the clinical conduct administered to such patients. ${ }^{33-36}$ 
In evaluating the 82 patients in the sample presented, we found predominance of the colors blue and yellow (74.4\%), which represents a predominance of $20-50 \mathrm{mmHg}$ and $50-80 \mathrm{mmHg}$. These mathematical values represented pressures of between 20 and $80 \mathrm{mmHg}$ that were observed at the anorectal walls. The highest pressure levels were correlated with the anal canal. This percentage was greater than the sum of the percentages of continent and partially continent patients (63.4\%). In other words, the graphical presentations showed better results than did the clinical behavior, which demonstrates potential for improving the state of continence, if appropriate training for this purpose is begun. Another element to be highlighted is the possibility for change in this color pattern, especially among the partially continent patients, who might start to present the pattern for continent patients after undergoing training through an appropriate exercise program.

The means for total and segmental anorectal asymmetry were similar between the three groups of patients (continent, partially continent and incontinent). These values were close to those considered normal in the literature. These data show us that the surgery was well executed from a technical point of view, although it is evident that, in addition to well-performed surgery, other factors are also involved in the state of continence following posterior sagittal anorectoplasty, such as the anatomy of the malformation.

We found a mean rectal volume of 280 $\mathrm{cm} \mathrm{x} \mathrm{cmHg}$. For the continent, partially continent and incontinent groups of patients, the mean values found were 279.4 , 349.2 and $167.1 \mathrm{~cm} \mathrm{x} \mathrm{cmHg}^{2}$, respectively. The differences were statistically significant $(\mathrm{p}=0.023)$, with the biggest difference between the continent and incontinent patients.

In our sample, the partially continent patients presented greater rectal volumes than did the other groups. This pattern portrays mixed behavior, with characteristics of the two end groups (continent and incontinent). On the other hand, patients with large rectal volumes, abnormal pressure curves of high intensity and large amplitudes, led us to a diagnosis of hypertonic sphincter, with fecal retention and fecal escapes at inappropriate moments, thus characterizing a condition of pseudo-incontinence. ${ }^{37-40}$

Posterior sagittal anorectoplasty has been shown to be an excellent technique for treating anorectal anomalies, and good results without greatly compromised neuromuscular structures have been achieved. Nonetheless, many patients may continue to present functional problems following surgery, reflected through varying degrees of fecal escape and constipation. ${ }^{41-45}$

CONCLUSIONS

Computerized anorectal manometry and profilometry are very useful methods for physiologically evaluating the anorectal region of children who have undergone surgery to correct anorectal anomalies. They are also very useful for postoperative follow-up and therapeutic planning, with objective and efficacious criteria.
1. Pena A, Devries PA. Posterior sagittal anorectoplasty: important technical considerations and new applications. J Pediatr Surg. 1982;17(6):796-811.

2. Sun WM, Rao SS. Manometric assessment of anorectal function. Gastroenterol Clin North Am. 2001;30(1):15-32.

3. Benninga MA, Omari TI, Haslam RR, Barnett CP, Dent J, Davidson GP. Characterization of anorectal pressure and the anorectal inhibitory reflex in healthy preterm and term infants. J Pediatr. 2001;139(2):233-7.

4. Goyal A, Williams JM, Kenny SE, et al. Functional outcome and quality of life in anorectal malformations. J Pediatr Surg. 2006; $41(2): 318-22$

5. Konuma K, Ikawa $\mathrm{H}$, Kohon $\mathrm{M}$, Okamoto $\mathrm{S}$, Masuyam $\mathrm{H}$, Fukumoto H. Sexual problems in male patients older than 20 years with anorectal malformations. J Pediatr Surg. 2006;41(2):306-9.

6. Funakosi S, Hayashi J, Kamiyama T, et al. Psychosocial liaison-consultation for the children who have undergone repair of imperforate anus and Hirschsprung disease. J Pediatr Surg. 2005;40(7):1156-62.

7. Mishalany H, Suzuki H, Yokoyama J. Report on First International Symposium of Anorectal Manometry. J Pediatr Surg. 1989;24(4):356-9.

8. Martins JL, Pinus J, Pinus JQ. Manometria anorretal. In: $\mathrm{Fa}-$ gundes Neto U, Wehba J, Penna FJ, editors. Gastroenterología pediátrica. $2^{\text {nd }}$ ed. São Paulo: Medsi; 1991. p. 805-11.

9. Cali RL, Blatchford GJ, Perry RE, Pitsch RM, Thorson AG, Christensen MA. Normal variation in anorectal manometry. Dis Colon Rectum. 1992;35(12):1161-4.

10. Martins JL. Avaliação pós-operatória de crianças portadoras de anomalias anorretais, submetidas à correção cirúrgica pela anorretoplastia sagital posterior. [Thesis]. São Paulo: Universidade Federal de São Paulo — Escola Paulista de Medicina; 1993.
11. Martins L, Esteves E. Evaluación de la motilidad anorrectal por manometría computarizada en la infancia. [Functional anorectal evaluation with computerized manometry in children]. Rev Cir Infant. 1996;6(4):177-80.

12. Martins JL, Pinus J. Use of biofeedback (BFB) in the treatment of fecal incontinence after surgical correction of anorecta malformations by posterior sagittal anorectoplasty (PSARP). Sao Paulo Med J. 1997;115(3):1427-32.

13. Allen ML, Zamani S, DiMarino AJ Jr, Sodhi S, Miranda LA, Nusbaum M. Manometric measurement of anal canal resting tone: comparison of a rectosphincteric balloon probe with a waterperfused catheter assembly. Dig Dis Sci. 1998;43(7):1411-5.

14. Hanneman MJ, Sprangers MA, De Mik EL, et al. Quality of life in patients with anorectal malformation or Hirschsprung's disease: development of a disease-specific questionnaire. Dis Colon Rectum. 2001;44(11):1650-60.

15. Boston VE, Scott JE. Anorectal Manometry as a diagnostic method in the neonatal period. J Pediatr Surg. 1976;11(1):9-16.

16. Bowes KL, Kling S. Anorectal manometry in premature infants. J Pediatr Surg. 1979;14(5):533-5.

17. Peña A. Surgical treatment of high imperforate anus. World J Surg. 1985;9(2):236-43.

18. Gordon PH. Anorectal anatomy and physiology. Gastroentereol Clin North Am. 2001;30(1):1-13.

19. Olsen AL, Rao SS. Clinical neurophysiology and electrodiagnostic testing of the pelvic floor. Gastroenterol Clin North Am. 2001;30(1):33-54, v-vi.

20. Varma JS, Smith AN. Anorectal profilometry with the microtransducer. Br J Surg. 1984;71(11):867-9.

21. Lestar B, Kiss J, Penninckx F, Istvan G,. Bursics A, Weltner J. Clinical significance and application of anorectal physiology. Scand J Gastroenterol Suppl. 1998;228:68-72.
22. Heikenen JB, Werlin SL, Di Lorenzo C, et al. Colonic motility in children with repaired imperforate anus. Dig Dis Sci. 1999;44(7):1288-92.

23. Vaizey CJ, Kamm MA. Prospective assessment of the clinical value of anorectal investigations. Digestion. 2000;61(3):207-14

24. Jorge JM, Wexner SD. Anorectal manometry: techniques and clinical applications. South Med J. 1993;86(8):924-31.

25. Schuster T, Lagler F, Pfluger T, Dietz HG, Joppich I. A computerized vector manometry and MRI study in children following posterior sagittal anorectoplasty. Pediatr Surg Int. 2001;17(1):48-53.

26. Rasmussen OO. Anorectal function. Dis Colon Rectum. 1994;37(4):386-403.

27. Langemeijer RA, Molenaar JC. Continence after posterior sagittal anorectoplasty. J Pediatr Surg. 1991;26(5):587-90.

28. Sundblad M, Hallbook O, Sjodahl R. Anorectal manometry with a microtransducer. Eur J Surg. 1993;159(6-7):365-70.

29. Sangwan YP, Coller JA, Schoetz DJ Jr, Murray JJ, Roberts PL. Latency measurement of rectoanal reflexes. Dis Colon Rectum. 1995;38(12):1281-5.

30. Tsuji H, Okada A, Nakai H, Azuma T, Yagi M, Kubota A. Follow-up studies of anorectal malformations after posterior sagittal anorectoplasty. J Pediatr Surg. 2002;37(11):1529-33.

31. Peña A, Hong AR, Midulla P, Levitt M. Reoperative surgery for anorectal anomalies. Semin Pediatr Surg. 2003;12(2):118-23.

32. Hool GR, Lieber ML, Church JM. Postoperative anal canal length predicts outcome in patients having sphincter repair for fecal incontinence. Dis Colon Rectum. 1999;42(3):313-8.

33. Taylor BM, Beart RW Jr, Phillips SF. Longitudinal and radial variations of pressure in the human anal sphincter. Gastroenterology. 1984;86(4):693-7. 
34. Williamson JL, Nelson RL, Orsay C, Pearl RK, Abcarian H. A comparison of simultaneous longitudinal and radial recordings of anal canal pressures. Dis Colon Rectum. 1990;33(3):201-6.

35. Keck JO, Staniunas RJ, Coller JA, Barrett RC, Oster ME. Computer-generated profiles of the anal canal in patients with anal fissure. Dis Colon Rectum. 1995;38(1):72-9

36. Benninga MA, Wijers OB, van der Hoeven CW, et al. Manometry, profilometry, and endosonography: normal physiology and anatomy of the anal canal in healthy children. J Pediatr Gastroenterol Nutr. 1994;18(1):68-77.

37. Chen CC, Lin CL, Lu WT, Hsu WM, Chen JC. Anorectal function and endopelvic dissection in patients with repaired imperforate anus. Pediatr Surg Int. 1998;13(2-3):133-7.

38. Peña A, Hong A. Advances in the management of anorectal malformations. Am J Surg. 2000;180(5):370-6.
39 Hrabovszky Z, Dewan PA. Revision anorectoplasty in management of anorectal anomalies. Pediatr Surg Int. 2002;18(4):269-72.

40. Hallows MR, Lander AD, Corkery JJ. Anterior resection for megarectosigmoid in congenital anorectal malformations. J Pediatr Surg. 2002;37(10):1464-6.

41. Nakayama DK, Templeton JM Jr, Ziegler MM, O'Neill JA, Walker AB. Complications of posterior sagittal anorectoplasty. J Pediatr Surg. 1986;21(6):488-92.

42. Belizon A, Levitt M, Shoshany G, Rodriguez G, Реп̆a A. Rectal prolapse following posterior sagittal anorectoplasty for anorectal malformations. J Pediatr Surg. 2005;40(1):192-6.

43. Rao SS, Patel RS. How useful are manometric tests of anorectal function in the management of defecation disorders? Am Gastroenterol. 1997;92(3):469-75.
44. Moss RL. The failed anoplasty: successful outcome after reoperative anoplasty and sigmoid resection. J Pediatr Surg. 1998;33(7):1145-7; discussion 1147-8.

45. Rintala RJ, Lindahl HG. Fecal continence in patients having undergone posterior sagittal anorectoplasty procedure for a high anorectal malformation improves at adolescence, as constipation disappears. J Pediatr Surg. 2001;36(8):1218-21.

Sources of funding: None

Conflict of interest: None

Date of first submission: May 5, 2006

Last received: May 21, 2007

Accepted: May 22, 2007
AUTHOR INFGRMATION

Pedro Félix Vital Júnior, MD, PhD. Pediatric surgeon, Universidade Federal de São Paulo - Escola Paulista de Medicina (Unifesp-EPM), São Paulo, Brazil.

José Luiz Martins, MD, PhD. Associate professor, Universidade Federal de São Paulo - Escola Paulista de Medicina (Unifesp-EPM), São Paulo, Brazil.

Fábio Luís Peterlini, MD, PhD. Pediatric surgeon, Universidade Federal de São Paulo - Escola Paulista de Medicina (Unifesp-EPM), São Paulo, Brazil.

\section{Address for correspondence:}

José Luiz Martins

Rua dos Otonis, 131 - Vila Clementino

São Paulo (SP) - Brasil - CEP 04025-000

Tel. (+55 11) 7100-0907 - Fax. (+55 11) 5575-4761

E-mail: jlmartins1@terra.com.br

Copyright @ 2007, Associção Paulista de Medicina

\section{Anorretoplastia sagital posterior em anomalias anorretais - avaliação clínica, manométrica e profilométrica}

CONTEXTO E OBJETIVO: As anomalias anorretais correspondem a um espectro de malformações de tratamento difícil mesmo nos dias de hoje. O objetivo foi avaliar crianças portadoras de anomalias anorretais altas e intermediárias, operadas pela anorretoplastia sagital posterior quanto à continência fecal através da manometria anorretal e profilometria computadorizadas.

TIPO DE ESTUDO E LOCAL: Trabalho prospectivo, na Universidade Federal de São Paulo.

MÉTODO: Avaliamos 82 pacientes agrupados em continentes, parcialmente continentes e incontinentes quanto a idade, sexo e variáveis padronizadas na manometria anorretal e profilometria. Os resultados foram analisados estatisticamente.

RESULTADOS: Dos 82 pacientes $37,8 \%$ eram continentes, $25,6 \%$ parcialmente continentes e $36,6 \%$ incontinentes. A média da pressão de repouso à manometria anorretal foi de $22 \mathrm{mmHg}$, sendo entre os continentes, parcialmente continentes e incontinentes, respectivamente de $30,7 \mathrm{mmHg}, 23 \mathrm{mmHg}$ e $14,7 \mathrm{mmHg}$. A média da resposta pressórica à contração voluntária foi de $56 \mathrm{mmHg}$, sendo entre os continentes $65,4 \mathrm{mmHg}$, parcialmente continentes $55,8 \mathrm{mmHg}$ e incontinentes $46,6 \mathrm{mmHg}$. $\bigcirc$ reflexo reto-esfincteriano encontrava-se ausente em $82,9 \%$ dos casos. Predominaram na profilometria as cores azul $(20$ a $50 \mathrm{mmHg}$ ) e amarela $(50$ a $80 \mathrm{mmHg}$ ), quando todo o grupo foi analisado conjuntamente, com padrão semelhante entre os continentes e parcialmente continentes; nos incontinentes, destacaram-se as cores verde $(<20 \mathrm{mmHg})$ e azul.

CONCLUSÕES: A manometria anorretal computadorizada e a profilometria mostraram-se úteis na avaliação do comportamento pressórico esfincteriano, assim como no acompanhamento pós-operatório e planejamento terapêutico dos pacientes.

PALAVRAS-CHAVE: Criança. Canal anal. Anus imperfurado. Manometria. Incontinência fecal. 